УДК [821.161.2-92.02.09:070.15]:356.113(477)《1915/1917»

DOI https://doi.org/10.24919/2308-4863/34-4-20

Ірина РОЗДОЛЬСЬКА, orcid.org/0000-0002-3308-1981 кандидат філологічних наук, доцент кафедри украӥнської літератури імені академіка Михайла Возняка Львівського національного університету імені Івана Франка (Львів, Україна) yaremchuk.iryna74@gmail.com

\title{
СТРУКТУРНІ ОСОБЛИВОСТІ І ГЕНЕРАЦЙНИЙ СТАТУС ПРЕСОВОЇ КВАТИРИ УКРАЇНСЬКИХ СІЧОВИХ СТРІЛЬЦІВ ЯК ЛІТЕРАТУРНОЇ СПІЛЬНОТИ
}

\begin{abstract}
Статтю присвячено з'ясуванню структурних особливостей Пресової Кватири Украӥнських Січових Стрільців (1915-1917) як літературної спільноти, ї̈ генераційного статусу. У процесі дослідження було прослідковано ї̈ ієрархічні зв'язки з Кошем Українських Січових Стрільців та Бойовою Управою Украӥнських Січових Стрільців. На основі залучених архівних джерел (установчого документа Пресової Кватири, її «Правильника» та друкованого органу «Вістник Пресової Кватири») зроблено висновок про статус спільноти як організації, робота якоі була чітко регламентована внутрішніми правилами, літературна діяльність якої становила окремий сегмент.

Заснування Пресової Кватири стало найважливішим структурним досягненням у Коші, яке уможливило літературний розвиток військового покоління. Історія появи інституиії бере свій початок від 9 березня 1915 року з ініціативи кошового отамана Никифора Гірняка та Миколи Угрина-Безгрішного у Замковій Паланці, згодом вона продовжслася в с. Свистільники.

Редакторами «Вістника Пресової Кватири Украӥнських Січових Стрільиів» стали Микола Угрин-Безгрішний та Антін Лотоцький. Також авторами були Юра Шкрумеляк, Андрій Бабюк (Мирослав Ірчан), Теодор Бобків. Перше число датовано 1 травня 1916 року. Актуальність Пресової Кватири як інституції полягала у систематичному зборі і збереженні матеріалів щодо історії стрілецького війська.

Пресова Кватира Українських Січових Стрільиів як літературна спільнота по суті є офіційною, організованою, включеною в ієрархію воєнних стрілецьких підрозділів великою кількісно, розлогою структурно організацією широкого гуманітарного спектру, в якому літературна діяльність суттєво актуалізувалася із чітко окресленою і прописаною метою, власним статутом і планом діяльності, за яким здійснювався культурний, освітній і літературний менеджменти.
\end{abstract}

Ключові слова: Украӥнські Січові Стрільиі, Пресова Кватира Украӥнських Січових Стрільців, літературна група, літературна організація.

Iryna ROZDOLSKA, orcid.org/0000-0002-3308-1981 Candidate of Philological Sciences, Associate Professor at the Department of Ukrainian Literature named after Academician Mykhailo Vozniak Ivan Franko National University of Lviv (Lviv, Ukraine) yaremchuk.iryna74@gmail.com

\section{STRUCTURAL FEATURES AND GENERATIONAL STATUS OF THE PRESS ROOM ("PRESOVA KVATYRA") OF THE UKRAINIAN SICH RIFLEMEN AS A LITERARY COMMUNITY}

The article is dedicated to the structural features of the Ukrainian Sich Riflemen Press Room ("Presova Kvatyra") (1915-1917) as a literary community - its generational status is clarified. The hierarchical links with the Ukrainian Sich Riflemen Reserved Military Unit ("Kish") and the Ukrainian Sich Riflemen Combat Command ("Boyova Uprava") were followed throughout the study. On the basis of the incorporated archive sources constituent document of the Press Room, its Rules of Procedure ("Pravylnyk"), and the organ of the "Newsletter of the Press Room" ("Vistnyk Presovoi kvatyry Ukrainskykh Sichovykh Striltsiv"), the status of the community as an organization was clearly defined by the rules, literary activity in which made a separate segment.

The establishment of the Press Room was a major structural and generational achievement in "Kish", which made literary development of military generation possible in the future. The history of the institution dates back to March 9 , 1915, on the initiative of the chieftain Nykyfor Hirnyak and Mykola Uhryn-Bezgrishnyi in the Zamkova Palanka, then in Svystilnyky village. 
The editors of the Press Room of the Ukrainian Sich Riflemen were Mykola Uhryn-Bezgrishnyi and Antin Lototsky, among them are Andrij Babiuk (Myroslav Irchan), Teodor Bobkiv. The first number is dated May, 1, 1916. The relevance of the Press Room as an in situation was the systematic and systematic collection and the presentation of materials to the history of the Riflmen army.

Thus, the Press Room of the Ukrainian Sich Riflemen as a literary community is essentially official, organized in the hierarchy of military riflemen units, large quantitatively, a broadly structured organization of the broad humanitarian spectrum, in which literary activity is substantially relevant, and the statute and plan of activities under which cultural, educational and literary management was carried out.

Key words: Ukrainian Sich Riflemen, Ukrainian Sich Riflemen Press Room ("Presova Kvatyra"), literary group, literary organization.

Постановка проблеми. Осмислення літературного феномену військової фаланги Українських Січових Стрільців на авансцені літературознавчих студій було започатковано через стильову актуалізацію їхньої практики, введення в історико-літературний обіг окремих персоналій Р. Купчинського, О. Бабія, В. Бобинського, а також групи «Митуса. Розвідки Т. Салиги», яка $є$ яскравим свідченням цього, що як і першу антологію стрілецької поезії «Стрілецька Голгофа», ï упорядкував Т. Салига. У процесі студій прийшло розуміння, що стрілецька творчість $є$ і детермінованою форматом тієї історичної дії, яку виконувало січове стрілецтво, і форматом військового покоління, яке почала формувати мілітаризована ще з часів сокільсько-стрілецьких парамілітарних товариств галицька молодь.

Тому необхідно приглянутися ближче до ідейно-естетичної специфіки літературного вияву стрілецького покоління, до тих літературних середовищ, які стрілецтво формувало протягом власної національно-визвольної траєкторії. Частково нам вдалося звернути увагу на певні літературно-генераційні формати стрільців періоду Визвольної війни 1914-1920 років, зокрема журнал «Світ» (Роздольська, 2020: 163-180), однак поза увагою літературознавців залишився ідейноестетичний формат такої групи як «Пресова Кватира», актуалізованої поки що лише в історичних студіях (Лазарович, 2016).

Аналіз досліджень. В українському літературознавстві лише нещодавно було актуалізовано структурно-генераційний підхід до явищ історико-літературного характеру, особливо в застосуванні до літературної практики письменників, здійснюваної в рамках літературної спільноти. Потреба в ньому виникає із поступовим поверненням на історико-літературну карту країни забутих за тоталітаризму явищ. В арсеналі українського літературознавства є розвідки про «Молоду Музу» i «Празьку школу» (Ільницький, 1995), «Київську школу української поезії» (Пастух, 2010), вісниківський феномен (Баган, 2009), літературно-ідеологічні напрями українського міжвоєння (Олій-
ник-Рахманний, 1990), в яких актуалізується поняття літературної групи як спільноти.

На теоретичному рівні маємо не такі пропозиції щодо структурної парадигми спільноти, а й розуміємо, що власна національна практика осмислення того чи іншого угруповання допоможе виробити продуктивні критерії. Літературознавча енциклопедія Юрія Коваліва фіксує цей стан, водночас дефініція пропонує дослідницькі горизонти, на які варто звернути увагу: «Група - спільнота письменників, об'єднана близькими творчими інтересами, стильовими уподобаннями, розумінням специфіки художньої творчості. Групи можуть бути малими і великими, організованими і стихійними, офіційними (формальними) i неофіційними (неформальними), корпоративними і дифузними, членськими і референтними, мати свого лідера або задовольнятися внутрішньою рівністю всіх представників. Вони $\epsilon$ органічним складником літературного процесу певного конкретно-історичного періоду: «неокласики», які вписуються в контекст «Розстріляного Відродження»; Нью-Йоркська група, яка найповніше в історії українського письменства реалізувала можливості модернізму» (Ковалів, 2007: 245).

Стрілецька генерація теж поступово входить в історію літератури, першою презентацією якої стала антологія Тараса Салиги (Стрілецька Голгофа, 1992). Нині структурні особливості літературного функціонування стрілецтва перебувають поза увагою наукової уваги. Єдина стрілецька група, належно описана в літературознавстві, «Митуса» (Сирота, 2004), інші ж спільноти спорадично озвучуються під час звернення до стрілецьких персоналій. Генераційний статус групи ми також з'ясовуємо (Роздольська, 2020: 4-9).

Метою статті $\epsilon$ реконструювати структуру такої стрілецької спільноти як «Пресова Ква-

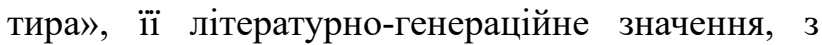
якою пов'язують творчий розвиток стрілецьких літературно-мистецьких сил у різних формах. Для аналізу буде залучено іiі статут і матеріли 3 друкованого видання групи, а також систематизовано необхідні історичні дані. 
Виклад основного матеріалу. У складі Легіону Українських Січових Стрільців, окрім власне бойових підрозділів, функціонувало чимало інших «легальних і нелегальних» модулів, які допомагали стрілецтву у здійсненні їхньої визвольної місії: «Кадра», «Кіш», «Збірні станиці», «Вишкіл», «Пресова кватира», бібліотека, мережа гуртків освітнього і мистецького культурного спрямування, які «визначали обличчя Легіону УСС та сприяли зростанню його популярності серед українського народу» (Лазарович, 2016: 223).

«Кадра», або «Запасна сотня УСС», або «Січовий Кіш» - офіційний підрозділ армії, створений у 1914 році в Горонді і Страбичево поблизу Мукачево (Яцків, 1917: 95). 3 березня 1915 року він перебував під орудою сотника Никифора Гірняка і набув «Скінченої форми» всіх своїх інституцій у Свистільниках (Яцків, 1917: 100). Завдання підрозділу - вербувати та вишколювати добровольців. Саме після славних і кривавих боїв під Семиківцями, які тривали від 9 вересня 1915 року до початку листопада 1915 року, в яких стрілецтво виявило «безприкладну хоробрість» (генерал Фляйшман), військо отримало відпочинок спочатку на два тижні у землянках біля ріки Стрипа, згодом з осені до зими перебувало на дислокації у Свистільниках біля Соснова і Тудинки (аж до травня 1916 року) (Українські, 1991: 54).

М. Лазарович встановив, що здатності до перманентного відновлення фізичних і моральних сил на фронті стрілецька формація повинна завдячувати діяльності Коша, в якому підвищували національну свідомість вояків і мілітарну (Лазарович, 2016: 224). Інші вербувальні стрілецькі формації УСС (Збірні станиці, Поборова станиця, Комісаріати УСС) також були задіяні в обширній просвітницькій роботі (Лазарович, 2016: 225). Кіш займався й реєстрацією стрілецьких кадрів, був місцем перепочинку стрільців, які відбули на фронт чи отримали поранення. Комунікація в Коші сприяла консолідуванню стрілецтва, більшому витворенню збірного «ми», сприйняттю себе «єдиним організмом». Кіш - «річ дуже важна, без неї стрілецтво завмре. Там осередок і жерело сил» (Лазарович, 2016: 133-134).

Б. Гнаткевич зазначає, що саме в атмосфері Коша виникла більшість ідей щодо гурткового, журнального структурування стрілецького колективу (Українські, 1991: 54), однак найважливішим структурним досягненням у Коші стало заснування «Пресової кватири». «Вишкіл» УСС також був формацією із «активним способом життя - як військового, так і національно-культурного», в якій велося і військове навчання ново- бранців, і духовне за допомогою різнотемних курсів. Тут було засновано «Закон Лицарів Залізної Остроги» (Українські, 1991: 82), спрямований на плекання товариської культури й формування характеру на базі вояцького лицарства (Лазарович, 2016: 242-243). Як пише Осип Назарук, тоді «мене просто осліплювала думка, що тут родиться цілком нове покоління українського народу, новий тип українця» (Назарук, 1917: 63).

Історія появи інституції бере початок від 9 березня 1915 року з ініціативи кошового отамана Никифора Гірняка та Миколи Угрина-Безгрішного у Замковій Паланці. До колективу долучився й Іван Горянський. У той час метою групи було «дроблення стрілецьких світлин і познакомлювання нашої й чужої преси про всї важнїшї прояви життя У.С.В.» (Угрин-Безгрішний, 1916: 9). Михайло Яцків називає Миколу Угрина-Безгрішного «основателем Пресової Кватири», а Никифора Гірняка - iї головою (Яцків, 1917: 99).

Спільнота заснувала власний друкований орган, який так і називався «Вістник Пресової Кватири Українських Січових Стрільців». Редакторами видання стали Микола Угрин-Безгрішний та Антін Лотоцький. Також авторами були Юра Шкрумеляк, Андрій Бабюк (Мирослав Ірчан), Теодор Бобків. Перше число датовано 1 травня 1916 року.

Микола Угрин-Безгрішний був переконаний в актуальності Пресової Кватири як інституції, спрямованої на збір і збереження матеріалів щодо історії стрілецького війська. Він навіть висловлював думку, що така структура мала б бути заснована набагато раніше, фактично синхронно з організацією Українських Січових Стрільців, оскільки за цей час від 1914 року зникло чимало важливих і цінних матеріалів. Подібну ідею про заснування Українського Пресового Бюро 26 серпня 1914 року висловив Ілько Цьокан у листі-зверненні до Української Бойової Управи. В ньому йшлося про формування структури при генеральному штабі, метою якої було б інформування чужинської преси, особливо віденської і берлінської «про наші мілітарні організації» і їхні успіхи, яка б концентрувала в собі стрілецьку інформаційну мілітарну політику і поширювала її назовні (Цьокан, 1914: 1-2).

Присвячуючи діяльності Пресової Кватири публікації, Микола Угрин-Безгрішний розгорнув масштаб стрілецької літописної діяльності загалом і літературної зокрема у справі увічнення визвольного подвигу УСС. Перше формальне засідання Пресової Кватири відбулося в Замковій Паланці 18 травня 1915 року. На ньому було обрано ii «старшину», оргкомітет: «Т. Мелень - орудник, М. Угрин-Безгрішний - заступник орудника й архі- 
вар, О. Калитовський - скарбник, М. Балицький та I. Горянський - писарі, Р. Купчинський і В. Огоновський - члени-помічники, Др. В. Старосольський увійшов до П. Кв. як делєгат З.У.Р. та У.Б.У.» (Угрин-Безгрішний, 1916: 10). Крім них, матеріально Кіш підтримували кошовий отаман, др. Іван Рихло, четар Ярослав Індишевський, підхорунжий Антін Жила та інші. До оточення Пресової Кватири також було зараховано таких стрільців як «полковник Гр. Коссак, сот. Дмитро Вітовський, кур. от. В. Дідушок, кур. от. Т. Рожанковський, кур. от. Сень Горук, др. А.Боляй та вся наша Старшина в полї» (Угрин-Безгрішний, 1916: 10).

Після загибелі «товариша орудника» Т. Меленя, його функції виконував Микола Угрин-Безгрішний до прибуття Осипа Назарука - кореспондента Української Боєвої Управи, наступного орудника Пресової Кватири, яким той був iз 2 червня 1915 року до 16 жовтня того ж року. Третім головою Пресової Кватири став Микола Угрин-Безгрішний. Також зазначено імена Івана Старчука - хроніста січового Коша, А. Баб'юка, Кл. Кузьмовича, М. Мушинського, Гр. Грицая, P. Сорохтея, С. Прідуна (Угрин-Безгрішний, 1916: 13), А. Дідика (Угрин-Безгрішний, 1916: 14), О. Куриласа, О. Демчука (Угрин-Безгрішний, 1916: 15). У проводі Пресової Кватири на фронті також називали Юліана Буцманюка, Івана Іванця (Граничка, 1929: 13). Серед інших співробітників був підхорунжий і мистецтвознавець Микола Голубець, музикант-десятник Антін Баландюк, Левко Лепкий (Лазарович, 2016: 231).

Зусиллями Івана Боберського було створено архів «мемуаристики, історії і пропаганди» стрілецтва. В її атмосфері розкрилися творчі таланти художника і «світливця» Ю. Буцманюка, «стрілецького співця» Романа Купчинського, Левка Лепкого, Осипа Куриласа, Івана Іванця, Юліана Назарака, Лева Геца, В. Бобинського, В. Оробця, хор. Талпаша, пхор. В. Старчука, віст. Ткачука, віст. Розумовича. Завдяки силовому впливу Пресової Кватири з'явилися стрілецькі художні і мистецькі твори - індивідуальні і колективні, якими є стрілецькі збірники (Українські, 1991: 121-123).

У 1917 році після бою під Конюхами Пресова Кватира втратила чимало співробітників, відтоді iii діяльність «стала принагідною» (Лазарович, 2016: 229). Вважається, що $з$ початком Визвольної війни всі ії працівники пішли «у бойові ряди» (Українські, 1991: 124). Згадують і про спроби стрілецтва на новому етапі визвольного руху у структурі бригади У.С.С. повторити традицію і також створити Пресову Кватиру, референтом якої став Андрій Бабюк, який «вів хроніку і про- паганду бригади», однак справа не мала успіху, у відділі обмежившись лише «пресовими і пропагандивними рефератами» (Українські, 1991: 124).

У спільноти був свій «Правильник» (статут) від 16 лютого 1916 року, в якому було зафіксовано структуру й обов'язки членів, особливості функціонування, масштаб (Правильник: 1-6). 3 його змісту можна зробити висновок про статус Пресової Кватири як спільноти, яка була формальною організацією із внутрішньою і зовнішньою ієрархією, установчими засадами, із ретельно прописаними завданнями для кожного члена. Підпорядковувалася вона Бойовій Управі УСС, функціонувала при Запасному Курені УСС. Р. Купчинський у листі до В. Старосольського зазначив, що «Пресова Кватира усьвячена полковим приказом» (Купчинський, 1915-1916: 19).

Організація мала свою управу («старшину»), яка складалася із голови (орудника), містоголови (заступника), писаря, господаря (завгоспа). Керівника Пресової Кватири призначала Українська Бойова Управа за згоди команданта Запасного Куреня, а членів старшини добирав голова Пресової Кватири за згодою команданта Запасного Куреня, затверджувала ж їх склад Бойова Управа (параграф 3).

Керівництво організації проводило регулярні засідання - відповідно до Правильника щодесять днів «коло 2-го, 12-го, 22-го» чисел у місяці. Засідання могли проводити й частіше, якщо голова ПК мав у цьому необхідність. Статут регулював питання кворуму (присутність трьох представників управи товариства), порядок денний засідань, правила проведення засідань (параграф 4). Усього таких зібрань від початку діяльності товариства до 1 травня 1916 року відбулося 30. Також було прописано правила «сходин» усіх членів товариства - раз на місяць із відповідним порядком денним. Стати членом Пресової Кватири можна було кожному, хто «зголоситься в голови і голова єго прийме, або той, котрого старшина візве до роботи» (Правильник: 3 ).

Пресова Кватира була інституцію, функціонально наділеною можливостями діяти в різних напрямах культурної, мистецької і наукової, підприємницької діяльності, адже передбачала роботу таких відділів: «письменників-дописувачів», музикантів, рисовників-різьбярів-малярів, світливців, науковців, видавничий, економічний. Діяльність кожного відділу була регламентованою відповідно до цілей пресової структури: «Члени мають представити образ трудів Українських Січових Стрільців під час європейської війни, яка зачалася в роцї 1914, а заразом представити образ терпінь українського населення в тій війні, щоби 
поширити сьвітогляд будучого українського покоління і піднести в нім українську народну сьвідомість і честь, а також, щоби предложити докази чинної участи українського народу в війні перед судом істориї» (Правильник: 1). Такі відділи потрактовані як «рухоме» представництво Пресової Кватири «в полі», «оба тоті товариства доповняють ся в роботі» (Правильник: 1).

Літератори були покликані «слідити» (спостерігати, досліджувати) розвиток усіх частин Запасного Куреня, нотувати спостереження про уклад життя воєнної спільноти і окремого стрільця, головні і другорядні події стрілецького життєвого укладу, враження стрільців, які прийшли 3 поля, щоб наповнювати пресовий дискурс яскравими сильветами «стрілецьких типів». Як і науковців, ïх мав би цікавити вплив війни на погляди населення, чи впливала вона «осьвідомлююче» на нього (Правильник: 5). Зі звіту Миколи УгринаБезгрішного можна зробити висновок, що Пресова Кватира організовувала стрілецьку літературну діяльність чи не на всій території стрілецького впливу. Колектив Кватири регулярно виїжджав у різні райони стрілецького ареалу в дослідницькі експедиції, проводив записи стрілецьких розповідей, авторські матеріали розсилав по українських часописах (Угрин-Безгрішний, 1916: 13).

Можливо, «Правильник» Пресової Кватири мав і певні доповнення, оскільки Микола УгринБезгрішний розширив «важніші точки» його змісту, зазначаючи, що після реорганізації товариства на початку квітня 1916 року він виготовив «регулямін», який було прийнято 3 квітня 1916 року. У ньому вказано тривалість робочого дня «щодня з виїмом українських свят і неділь від 8-12 год в пол. та від 3-6 вечером» (Угрин-Безгрішний, 1916: 11), форму звітності та дисциплінарного впливу на члена товариства.

Так, звіти про діяльність необхідно було подавати щодня у письмовій формі в спеціально заснованій для цього «книзі звідомлень». За «неточне сповнювання обов'язків по одноразовім упімненні старшина більшістю голосів виключає даного члена з Пр. Кв., а в оправданій та конечній потребі сам орудник навіть без упімнення про що повідомляє рівночасно Владу Коша У.С.С.». Так, «Роман Сорохтей за довгий час членування від 23 липня 1915 року не дав нічого, тому вичеркнено його з членів П. Кв. дня 3. IV.1916 (ex praesidio)» (Угрин-Безгрішний, 1916: 13). Однак стрільці не завжди дотримувалися цих пунктів, зокрема «тов. А. Бабюк виступив із членів П. К. без подання причин» (Угрин-Безгрішний, 1916: 16).

Кватира заснувала окрему лінійку внутрішніх документів, власну номенклатуру справ, тематика яких характеризує товариство як канцелярську установу 3 розлогою системою документування, серед яких «Переписна Книга та книга приказів», «Реєстр письм і статтів», «Книга звідомлень», «Реєстр літописних праць», Реєстр рисунків, світлин і карикатур», «Реєстр друків», «пачки резерватів, праць і документів до переписування», «первописи», «дуплікати» (архів) (Угрин-Безгрішний, 1916: 12).

Висновки. Отже, Пресова Кватира Українських Січових Стрільців як літературна спільнота по суті є офіційною, організованою, включеною в ієрархію воєнних стрілецьких підрозділів великою кількісно, розлогою структурно організацією широкого гуманітарного спектру, в якій літературна діяльність суттєво актуалізувалася і виокремлювалася із чітко окресленою і прописаною метою, власним статутом і планом діяльності, за яким здійснювався культурний, освітній і літературний менеджменти.

Згодом ця структура скеровуватиме творчість січового стрілецтва у часописі «Шляхи», іiі учасники братимуть участь у створенні вказаного знакового літературного середовища, головних видань - збірника «Тим, що впали», рукописної «Антольогії стрілецької творчості», скеровуватимуть творчість окремих стрільців, окреслюватимуть коло усіх причетних. У науковій перспективі - осмислення усіх творчих напрямів цієї структури зі встановленням ролі в ідейно-мистецькому розвитку стрілецької поколіннєвої ланки.

\section{СПИСОК ВИКОРИСТАНИХ ДЖЕРЕЛ}

1. Баган О. Вісниківство як понадчасовий феномен: ідеологія, естетика, настроєність. Вісниківство: літературна традиція та ідеї. Збірник наукових пращь, присвячений пам'яті Василя Іванишина / Ред. колегія: Л. Кравченко (голова), О. Баган, П. Іванишин та ін. Дрогобич : Коло, 2009. С. 6-48.

2. Граничка Л. Як я був усусусом. Як писався літопис проф. Боберського. Літопис Червоної Калини. 1929. № 3. С. 12-13.

3. Ільницький М. Від «Молодої Музи» до «Празької школи». Львів : Інститут Українознавства НАН України, Львівський обласний методичний інститут освіти, 1995. 318 с.

4. Купчинський Р. Лист до В. Старосольського [1915-1916]. ЦДІАЛ. Ф. 360. Спр. 519. Арк. 19-22.

5. Лазарович М. Легіон Українських січових стрільців: формування, ідея, боротьба. 2-ге вид, доп. Тернопіль : Джура, 2016. 628 с.

6. Літературознавча енциклопедія: У 2-х т. Т. 1. / Ред.-упорядник Ю. Ковалів. Київ : ВЦ «Академія», 2007.608 с. 
7. Назарук О. Над Золотою Липою. В таборах УСС. Б. м., 1917. 104 с.

8. Олійник-Рахманний Р. Літературно-ідеологічні напрями в західній Україні (1919-1939 роки). Київ : Четверта хвиля, 1990. $240 \mathrm{c}$.

9. Пастух Т. Київська школа та їі оточення: (модерні стильові течії української поезії 1960-90-х років) : монографія. Львів : ЛНУ імені Івана Франка, 2010. 700 с.

10. Правильник Пресової Кватири Українських Сїчових Стрільцїв. ЦДІАЛ. Ф. 353. Спр. 8. Арк. 1-6.

11. Роздольська І. Літературна група Українських Січових Стрільців «Митуса»: ідейно-естетичні засади і генераційний статус. Актуальні питання гуманітарних наук : міжвузів. зб. наук. пр. молод. вчених Дрогобицького державного педагогічного університету імені Івана Франка. Дрогобич : Видавничий дім «Гельветика», 2020. Вип. 28. Т. 4. С. 4-9.

12. Роздольська I. Журнал «Світ» як літературна платформа Українських Січових Стрільців. Наукові записки Харківського начіонального педагогічного університету імені Г. С. Сковороди: літературознавство. Київ : Видавничий дім Д. Бураго, 2020. Вип. 1 (95). С. 163-180.

13. Салига Т. Літературна група «Митуса» і друга хвиля українського символізму. Другий Міжнародний конгрес україністів. Львів, 1993. C. $168-173$.

14. Сирота Л. Літературна група «Митуса» (1921-1922): О. Бабій, В. Бобинський, Р. Купчинський, Ю. Шкрумеляк: бібліографічний покажчик / НДЦ періодики. ЛНБ ім. В. Стефаника. НАН України. Львів, 2004. 190 с.

15. Стрілецька Голгофа: спроба антології / Упоряд., авт. вступ. ст. і прим. Т. Ю. Салига. Львів : Каменяр, 1992.339 с.

16. Угрин-Безгрішний М. Пресова Кватира У.С.С. Вістник Пресової кватири Украӥнських Січових Стрільиів. Кіш Українського Січового Війська, 1916. Місяця мая. Ч. 1. С. 9-14.

17. Угрин-Безгрішний М. Пресова Кватира У.С.С. Вістник Пресової Кватири Українських Січових Стрільи̧ів. Кіш Українського Січового Війська, 1916. Місяця червня і липня. Ч. 2-3. С. 15-16.

18. Українські січові стрільці. 1914-1920 / за ред. Б. Гнаткевича. Репринт. відтворення з вид. 1935 р. Львів : Слово, 1991. $160 \mathrm{c}$.

19. Цьокан І. До Української Боєвої Управи у Львові, 1914 р., 26 серпня. ЦДІАЛ. Ф. 360. Спр. 19. Арк. 1-2.

20. Яцків М. До історії Коша У.С.В. Від самого початку аж по кінець марта 1916 р. на основі зібраних на місці записок. Тим щзо впали. Літературно-мистецький збірник. Кн. 1. / Зложив М. Голубець, украсив І. Іванець. Артистична Горстка і Пресова Кватира УСС в поли. Львів, 1917. С. 95-111.

\section{REFERENCES}

1. Bahan O. Visnykivstvo yak ponad chasovyi fenomen: ideolohiia, estetyka, nastroienist [Visnykivstvo as a more than temporal phenomenon: ideology, aesthetics, attitude]. Visnykivstvo: literary tradition and ideas. Collection of scientificworks dedicated to the memory of Vasyl Ivanyshyn. Drohobych : Kolo, 2009. P. 6-48 [in Ukrainian].

2. Hranychka L. Yak ya buv usususom [How to be an Ususus. Yow was writing a chronicle of prof. Boberskyy]. Chronicle of Chervona Kalyna, 1929. № 3. P. 12-13 [in Ukrainian].

3. Ilnytskyy M. Vid "Molodoi Muzy" do "Prazkoi shkoly" [From "Young Muse" to "Prague School"]. Lviv, 1995. 318 p. [In Ukrainian].

4. Kupchynskyy R. Lyst do V. Starosolskoho [Letter to V.Starosokskyy [1915-1916]. The Central State Historical Archives. Lviv, Ukraine. Fund 360. Folder 519. P. 19- 22 [in Ukrainian].

5. Lazarovych M. Legion Ukrainskykh sichovykh striltsiv: formuvannia, ideia, borotba [Legion of Ukrainian Sich Riflemen: formation, idea, struggle]. Ternopil : Dzhura, 2016. 628 p. [in Ukrainian].

6. Literaturoznavcha entsyklopediyia [Literary Encyclopedia]. Kyiv : Akademiya, 2007. Vol. 1. 608 p. [in Ukrainian].

7. Nazaruk O. (1917). Nad Zolotoiu Lypoiu. V taborakh USS [Over the Golden Lypa. In the USS camps]. 1917. 104 p. [in Ukrainian].

8. Oliinyk-Rakhmannyi R. Literaturno-ideolohichni napriamky v Zakhidnii Ukraini (1919-1939 roky) [Literary and ideological trends in Western Ukraine (1919-1939)]. Kyiv : Chetverta khvylia, 1999. 240 p. [In Ukrainian].

9. Pastukh T. Kyivska shkola ta yii otochennia: (moderni stylovi techii ukrainskoi poezii 1960-90-kh rokiv) : monohrafiia. [Kyiv school and its surrounding (modern stylistic currents of Ukrainian poetry of 1960-90-s : monograph]. Lviv, 2010. 700 p. [in Ukrainian].

10. Pravylnyk Presovoi Kvatyry Ukrainskykh Sichovykh Striltsiv (1916). [Rules of the Press Apartment of Ukrainian Sich Riflemen, 1916]. The Central State Historical Archives. Lviv, Ukraine. Fund 353, Folder 8. P. 1-6 [in Ukrainian].

11. Rozdolska I. Literaturna hrupa Ukrainskykh Sichovykh Striltsiv "Mytusa": ideino-estetychni zasady i heneratsiinyi status [Literary group of Ukrainian Sich Riflemen: ideological and aesthetic principles and generational status]. Topical issues of the humanities: an intercollegiate collection of researchers working with young people with Drohobych workers at Ivan Franko University. Drohobych : Helvetyka, 2020. Iss. 28. T. 4. P. 4-9 [in Ukrainian].

12. Rozdolska I. Zhurnal "Svit" yak literaturna platforma Ukrainskykh Sichovykh Striltsiv [Svit (World) magazine as a Literary platform of the Ukrainian Sich Riflemen]. Scientific notes of Kharkiv National Pedagogacal Univrsity named after H. Skovoroday: literary criticism. Kyiv : D. Buraho Publishing House, 2020. Issue 1 (95). P. 163-180 [in Ukrainian].

13. Salyha T. Literaturna hrupa "Mytusa" i druha khvylia ukrainskoho symvrlizmu [The "Mytusa" literary group and second wave of Ukrainian Symbolism]. The second International Congress of the researches of Ukrainian themes. Lviv, 1993. P. 168-173 [In Ukrainian].

14. Syrota L. Literaturna hrupa "Mytusa" (1921-1922): O. Babii, V. Bobynskyy, R. Kupchynskyi, Yu. Shkrumeliak: bibliohrafichnyi pokazhchyk [The "Mytusa" literary group: (1921-1922): O. Babii, V. Bobynskyy, R. Kupchynskyy, Yu. Shkrumeliak: bibliographic index. Lviv, 2004. 190 p. [In Ukrainian]. 
15. Striletska Holhofa: sproba antolohii. [Riflemen Golgotha: an attempt at an Antology]. Lviv : Kamenyar, 1992. 339 p. [in Ukrainian].

16. Uhryn-Bezghrishnyy M. Presova Kvatyra U.S.S. (1916). [The Press Room of Ukrainian Sich Riflemen, 1916]. Bulletin of the Press Room of Ukrainian Sich Riflemen. Kish of the Ukrainian Sich Army, 1916. № 1. P. 9-14 [in Ukrainian].

17. Uhryn-Bezghrishnyy M. Presova Kvatyra U.S.S. (1916). [The Press Room of Ukrainian Sich Riflemen, 1916]. Bulletin of the Press Room of Ukrainian Sich Riflemen. Kish of the Ukrainian Sich Army, 1916. №№ 2-3. P. 15-16 [in Ukrainian].

18. Ukrainski sichovi striltsi 1914-1920 [Ukrainian Sich Riflemen 1914-1920]. Lviv : Slovo, 1991. 160 p. [in Ukrainian].

19. Tsokan I. Do Ukrainskoi Boievoi Upravy u Lvovi, 1914, August, 26 [To the Ukrainian Combat Command in Lviv, 1914, August, 26]. The Central State Historical Archives. Lviv, Ukraine. Fund 360, Folder 19. P. 1-2 [in Ukrainian].

20. Yatskiv M. Do istorii Kosha U.S.V. Vid samoho pochatku azh po kinets marta 1916 r., na osnovi zibranykh na mistsi zapysok. [To the history of Kish of the Ukrainian Sich Riflemen. From the beginning until the end of March 1916, on the basis of notes collected on the spot]. Those who dead: literary and artistic collection. Lviv, 1917. Book 1. P. $95-111$ [in Ukrainian]. 